\title{
STREAM DigLIM: Learning Innovation in Madrasah to Develop Students' Literacy
}

\author{
Desi Wulandari ${ }^{1, *}$ Siti Mutmainah ${ }^{2}$ Hari Prastyo $^{3}$ Shiva Fauziah $^{4}$ \\ Teguh Fachmi ${ }^{5}$ Erna Sundari ${ }^{6}$ Husni Mubarok ${ }^{7}$
}

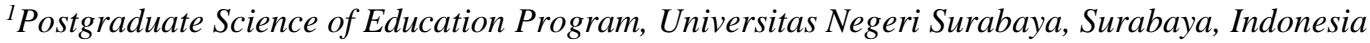 \\ ${ }^{2}$ Chemistry of Education Program, Universitas Negeri Surabaya, Surabaya, Indonesia \\ ${ }^{3}$ Islamic Education Department, Institut Agama Islam Uluwiyah, Mojokerto, Indonesia \\ ${ }^{4}$ MAN 1 Jepara, Jepara, Indonesia \\ ${ }^{5}$ Department of Early Childhood Islamic Education, UIN Sultan Maulana Hasanuddin, Banten, Indonesia \\ ${ }^{6}$ MTsN 11 Tasikmalaya, Tasikmalaya, Indonesia \\ ${ }^{7}$ National Taiwan University of Science and Technology, Taiwan \\ *Corresponding author. Email: desi.20010@mhs.unesa.ac.id
}

\begin{abstract}
New era COVID-19 pandemic requires teachers and students to understand technology. Along with the times, various kinds of latest innovations will appear, such as the novelty of digital learning. This study aims to analyze profile of STREAM DigLIM during the COVID-19 pandemic era and the recommendations of learning policymakers. The research method used in-depth analysis of literature studies related to learning innovation in madrasas, then the results of the literature were used to create new ideas related to digital learning innovations in Madrasah called STREAM DigLIM. STREAM DigLIM is a Scientific, Technology, Religious, Engineering, Art, and Mathematical Digital Learning Innovation in Madrasah. Profile of the STREAM DigLIM approach has characteristics of being based on science, technology, religion, engineering, art, and mathematics by maximizing digital potential of the latest technology. Characteristics of this approach in aspects of religion and art into learning in Madrasahs are literacy. The main objective of this approach is to train students' literacy, train students' religious skills and basic technology skills during the learning process. The researcher's recommendation about learning policy is the concept of STREAM DigLIM approach in learning. Where the religious aspect is emphasized during learning process. And this is packed with elements of art. The results of this study are used as empirical evidence that digital learning innovation needs to be developed and created, especially digital learning innovation media.
\end{abstract}

Keywords: Digital learning, Students’ literacy, Learning innovation, Madrasah, and STREAM Diglim.

\section{INTRODUCTION}

The Covid-19 pandemic has brought many changes in the field of education, both at the elementary school, junior high school, final high school, and college level. Learning in the classroom has changed to online learning; so that distance learning is an alternative to minimize the transmission of Covid-19 among education [1]. Distance learning affects student learning outcomes both in the cognitive, psychomotor, and attitudinal domains [2-3]. Students remain enthusiastic in learning to be the hope of teachers and parents when learning online.
Learning innovation in the pandemic era is an alternative solution in continuing learning in schools. Teachers and parents have tried to survive in continuing the students' learning process at home. Utilizing digital learning innovation features such as zoom, google classroom, google meet, and other features simplifies the learning process [4-6]. Some of these media are classified as digital learning innovations to train student literacy. Madrasah-based innovation digital learning during the pandemic needs to be developed much better [7]. One of the learning innovations in madrasah has been created by the ministry of religion in the form of e-learning madrasah [8]. 
Madrasah have developed web-based e-learning, but need further innovation related to the development of digital-based innovation digital learning (applications without the need for an internet network) [8-9]. The novelty of digital learning without the help of the internet must be developed again to develop students' literacy. So the uniqueness, creativity, and integration of artistic and religious aspects in each sub-material are very much needed by madrasah in developing digital learning innovations [11].

Art is needed in developing digital learning innovations so that students are more interested in learning. Digital learning can be integrated with STREAM. STREAM is Scientific Technology Engineering Art and Mathematics. Aspects of religion and arts in STREAM can be integrated into digital learning innovation. Aspects of art and religion can be integrated when the learning process begins. One of them can be done by giving animation in a religious context and the form of art or hunting. Understanding the use of technology is an important factor in today's education. Thus, it is necessary to conduct a research or idea that focus on observing the STREAM profile of DigLIM in era Covid-19 pandemic.

Problems in online learning are often felt by parents, teachers, and students, plus the weakness in solving problem-based solutions. The weakness of students in solving problems is caused by the lack of student reading literacy. These problems start from students feeling uncomfortable when learning online due to monotonous learning, which results in frustration and confusion [10]. DigLIM STREAM learning needs to be developed. This learning needs to be applied because it has the benefit of reducing stress due to new habits by creating education in the form of art in every learning feature. STREAM DigLIM also improves emotional performance for students and teachers with religious features in learning technology. These integrated technology features will make it easier for teachers, parents, and to develop students' literacy.

\section{METHODS}

\subsection{Type of Research}

This research used descriptive qualitative research with an in-depth analysis of the literature review. Literature review process came from theory and research of the latest national and international journals. The analysis process was made by examining in depth the topic of learning innovation in Madrasahs. The results of the study were used to find new findings or develop previous findings. New ideas were analyzed based on Madrasah innovation learning and digital learning technology.

\subsection{Research Procedure}

- Collection of topic literature was searched by writing keywords for "learning innovation", "learning madrasah", and "digital learning" on the Google Scholar and Scopus webs.

- In-depth analysis was made to compare and collaborate from the findings of each article

- Creating ideas, namely STREAM DigLiM, was done after reducing and analyzing from several articles

\section{DISCUSSION}

\subsection{Profile of STREAM DigLIM: New Era in COVID-19 Pandemic}

\subsubsection{Characteristics}

Characteristics of Digital Learning focuses on technology, applications, and the web in learning process. STREAM DigLIM is one of the ideas to create a learning approach based on science, technology, religion, engineering, art, and mathematics by maximizing the potential of the latest technology to develop student's literacy. Characteristics of approach STREAM DigLIM were developed by researchers in the religious aspect of digital learning in Madsarah. Indicator was developed based on analysis of Digital Learning approach in Madrasah. [12-13] stated that Madrasah are highly integrated with religious knowledge in each subject matter.

Students need to emphasize religious attitudes during learning. Emphasis on religious attitudes can be inserted in the learning syntax where each learning process is adjusted by the teacher based on the facilities owned by the Madrasah, including technology. The technology used can be a distance learning platform. The characteristics of STREAM DigLIM apart from emphasizing technology and religion, also emphasize artistic aspects during the learning process to develop student's literacy. The idea by a researcher is supported by [14] that the technology-based learning model by integrating religious aspects in learning materials provides students' initial learning motivation. Indirectly students learn how to apply religious attitudes during the learning process. Digital technology developed in the form of science, art, religion, is integrated with literacy in every reading. Research [15] states that religiousbased learning is easier to apply with behavioral learning. Where students are directly involved in activities. This characteristic of learning leads to the behavioristic theory. 


\subsubsection{Main Objective}

The main objective of DigLIM's STREAM approach is to create students' religious skills into technologybased learning materials to develop student's literacy. Another goal is to train students' religious abilities towards learning materials. Religious skills of students can be trained by giving Islamic motivation during the opening of material. Motivation can be delivered in the form of videos or animations so that learning contains art. [16] stated that most students will be motivated when given an interesting animated video. Millennial students are currently more interested in technology-based learning. Because millennial students currently have a large share of their activities explored through social media the learning process.

In addition, the goal of DigLIM's STREAM approach will also improve students' skills in using technology. Students will be trained in using technology, processing technology, and communicating technology. To increase students' curiosity, the application of this approach will be integrated with the artistic aspect. Art is needed in organizing learning materials to make it easier for students to understand the material. Innovative ideas are needed in compiling learning materials [17].

\subsubsection{Syntax}

In general, the DigLIM STREAM syntax consists of 3 parts, namely opening, content, and closing. The first is the opening. In the opening process, the teacher guides students by providing apperception of learning materials with religious attitudes in everyday life. Making the apperception can be poured in form of video, text, or animation at the beginning of learning to build student literacy. The learning context includes the use of general technology, technology communication, technology collaboration, and content production through technology [18]. The closing section includes evaluation. Evaluation of learning related to procedures in using technology and evaluation related concept learning materials.

Teachers need to prepare materials in advance in implementing religious-based digital learning in madrasah. When students need less deepening of the material, students can deepen the material from the internet or other electronic media. Students can deepen material through online sites. Teachers can also apply to learn through live streaming practice activities, and measure mastery through online quizzes and tests. Learning using digital access equipped with videos makes it easier for students to understand [18]. In addition, the learning presented is based on life problems. Reading problems will invite students in the process of reasoning, analysis, and communicative towards solutions.

\subsubsection{Reaction Principle}

The reaction principle contains how the teacher implements the STREAM DigLIM approach during the learning process. In carrying out this approach, teachers need to have skills in using technology. The basic skills of technology need to be possessed by teachers during the learning process. When the teacher has the skills earlier then the students will be easier to follow. Basic technology skills contain skills to use computers, investigate, and communicate technology well [19]. Then reaction principle of this learning is suitable using the Theory of Reasoned Action. This theory puts forward relationship between behavior, attitudes and norms [20]. Because it is feared that students' attitudes will disappear when the focus is on digital technology.

\subsubsection{Social Principles}

The social principle contains how teachers communicate with students when using the STREAM DigLIM approach. In carrying out this approach, a constructive learning theory is needed where students need step-by-step teacher guidance in madrasah. The step-by-step guidance will make students understand how to apply a learning technology. Students will learn based on their experience [21]. The learning process of this approach is dominant in technology learning which is integrated with religious skills.

Teachers need to interact with student's step-by-step to make it easier for students to understand learning instructions [22]. Step by step to achieve the learning objectives. Then students need to respond well to the direction of the teacher. Interactive communication is necessary for this learning approach. Because interactions are carried out remotely but are brought closer to technology media. This approach is suitable for using the principle of experiential learning. The initial experience gained by students will facilitate learning at a later stage. This is supported by research [23] that technology-based learning is easier to understand step by step on Islamic religious material.

\subsubsection{Learning Environment Management}

An innovative learning environment in the STREAM DigLIM approach can be done with direct learning but can use cooperative learning in completing tasks. The two learnings will complement each other if students exchange information and discussion ideas, including online. An attractive learning environment will make students not easily bored [24-25], therefore learning innovations by playing animations or videos further increase students' enthusiasm for learning.

DigLIM STREAM approach is more specifically using behavioristic learning. Where students will learn from the experiences they have gained. When students 
first access technology, they try to understand the meaning of each stage. However, once students get used to accessing the technology, it will be easier for them to use it. After that, students will explore the information they know from what they have learned. This behavior theory is suitable for students to use in integrating their knowledge of religion. According to [26] states that the behavioral theory is suitable for use in Islamic religious learning and is in line with the Islamic religion.

\subsubsection{Synergy of digital learning innovations in Madrasah}

The Ministry of Religion provides full support for digital learning for madrasah. Support can change to convey ideas, provide tools and media to facilitate Indonesian education in learning. By [27] that to optimize Indonesian education is facing distance learning, the Ministry of Religion is synergizing Indonesia through a digital learning platform with a target of 500 thousand madrasah students. Results of this agreement were built with the signing of an agreement between ministry of religion and UAE (Alef Education) regarding the use of technology. Empowerment of digital learning innovation platforms as a means to strengthen numerical literacy for madrasah students to create a dignified world-class [28]. Through a variety of learning technologies, students will easily access materials globally and students will be motivated to have a high curiosity through digital learning [29].

The provision of digital innovation learning can be done by conducting webinars or online seminars for teachers and students. This defense is to provide insight for teachers to continue to hone skills in applying digital learning innovation [30]. It was noted that nearly 5000 Madrasah Tsanawiyah (MTs) and Madrasah Aliyah (MA) teachers from all over Indonesia participated in the webinars planned by the Ministry of Religion. The Ministry of Religion has reinforced for thousands of madrasa teachers regarding digital learning. The strengthening is to provide insight, techniques, methods, and opportunities for teachers to continue to develop in a globalized world.

One of the webinars on digital learning will increase teacher awareness. Importance of madrasa teachers adapting the learning approach in the classroom. In today's digital era, teachers must prepare future generations to be ready to be part of the world community. One of the profiles to see the readiness of digital innovation learning in Madrasahs is seen from how the preparation of teachers and the government in facing digital learning in the Covid-19 pandemic [31].

\subsection{The Strength \& the Weaknesses of Digital Learning Innovation in Madrasah (STREAM DigLIM): New Era in COVID-19 Pandemic}

The Strength of innovative digital learning are that it can be accessed easily, costs are more affordable, study times are flexible, and students have broad insights [32].

\subsubsection{First, easily accessible}

Simply using a smartphone or other technological device such as a laptop connected to the internet, students can access the material they want to learn. By implementing digital learning, students can carry out learning activities anywhere, anytime. Not limited by time and place [33].

\subsubsection{More affordable cost}

Digital learning makes it easier for students to access knowledge without being constrained by missing lessons because they don't have the cost to buy manuals. Students just need to find a place that has free internet access. By seeking free internet access, students are easier to recognize new environments and new learning places [34].

\subsubsection{Flexible study time}

Most students do not have enough time to study, one of which is constrained by participating in many organizational activities and programs. The limited-time for student learning can be changed by applying digital learning. Through digital learning students are not limited by time. Learning that is accessed by students can be studied independently and at any time. Students can also repeat information from the teacher if they have learning recordings so that digital learning makes it easier for students to determine study times [34].

\subsubsection{Extensive knowledge}

The application of digital learning makes students discover many things that were previously unknown to be known. This is because the subject matter available in digital learning is not yet available in print media (books) [35]. Students will maximize their time to multiply and deepen their knowledge. Then students are also easier to explore the concept of subject matter with the help of digital learning.

\subsubsection{Practice student skills}

Accessing STEAM Digital learning requires basic skills in using technology. In accessing technology, skills are needed in understanding technology features, managing technology, and conveying technology. Students will be skilled at having a high curiosity in 
accessing technology [36]. In addition, in STREAM DigLIM students will get used to understanding religious attitudes because this approach is integrated with religious aspects. Students' imagination will also be trained because it is equipped with art-based videos and animations.

While the disadvantages of digital learning innovation include limited internet access, reduced interaction with teachers, understanding of the material, and lack of supervision in learning [36].

\subsubsection{Limited internet access}

If students do not have stable internet coverage, it will be difficult for students to access digital learning [37]. Of course, this still happens a lot in Indonesia, considering that some 3T areas (lagging, leading, and outermost) are still not covered by internet access. In addition, the price of using internet data is still considered quite expensive for some Indonesian people. This causes the ability to take advantage of digital learning is still considered a privilege.

\subsubsection{Less interaction with teachers}

Some digital learning methods are one-way. This causes the interaction of teachers and students to be reduced [37] so that it will be difficult for students to get further explanations about material that is difficult to understand. Understanding of the material taught during digital learning is responded based on different levels of understanding, depending on the ability of the user. Some people may be able to grasp material faster just by reading, but there are also those who take longer to really understand. There are even students who need an explanation in advance to understand the material being studied [38], so an evaluation of student learning outcomes during learning is needed.

\subsubsection{Lack of Supervision in Learning}

Lack of supervision in digital learning makes students lose focus on learning. Easiness of access makes students tend to procrastinate when studying [39-40]. Some students tend to be less assertive in managing study time if they do not have a fixed schedule. Self-awareness and parental supervision are needed so that the online learning process becomes directed and can achieve learning objectives.

\subsection{The Recommendation for Policy Maker in Indonesia}

The response of Indonesia toward learning in the era of the COVID-19 pandemic has been going well. This can be seen from the handling of changes in education policy at the beginning of the pandemic. Indonesia has implemented a swift policy by changing the 2013 curriculum to independent learning [41], equalizing the learning quota for students, teachers, and lecturers. This is a quick effort by the ministry of education in responding to the pandemic situation. Then breakthroughs regarding applications and other innovative learning media are also discussed and applied.

Based on a breakthrough and demands of education that must involve skills in the 21st century, researchers offer a policy implementation as an effort to develop digital learning performance. The concept of digital learning designed by researchers is called the "STREAM DigLIM" approach. This concept integrates the STREAM approach with Digital Learning Innovations in Madrasah to develop student's literacy [42]. The concept of integration is based on Science, Technology, Religion, Engineering, Art, and Mathematics. The STREAM concept is integrated with religious attitudes into digital learning, according to Madrasah institutions that are under the auspices of Religion. Based on a research [43], it is stated that elementary school teachers were very enthusiastic about the STREAM learning design. STREAM is a bridge in integrating religion, technology, and education.

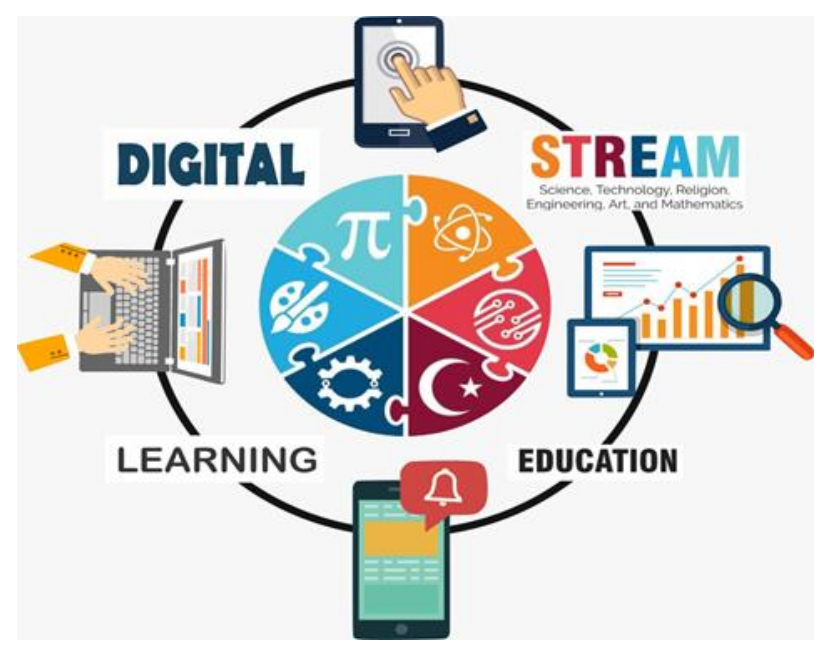

Figure 1 Concept of "STREAM DigLIM" approach.

Figure 1 shows the design ideas created by researchers in integrating STREAM [44] and Madrasah Digital Learning. The design ideas are to make digital learning breakthroughs. Digital learning implemented by teachers and students really needs to be integrated with Technology, Religion, Engineering, Art and Mathematics. Teachers have implemented digital learning very well. It needs to be integrated with the Religion approach according to the STREAM approach [44]. It is also necessary to develop science in the management of practical experiments or scientific experiments. The application of digitalization with the development of scientific experiments in each material still needs to be created again to make it easier for students to hone skills and knowledge. 
The researcher's recommendations for policymakers are the most important in era of digital learning, first, related to attitudes and behaviors as outlined in writing and practice during the teaching process. This attitude can be placed by providing Islamic motivation in digital learning [45]. Attitudes that must be developed are turning on the camera when teacher explains the material and when answering questions from teacher.

Second, researchers need to develop optimally in the virtual practicum media section. Digital practicum media is very much needed by students, especially in the field of science. Scientific-based technology needs to be developed again based on the material and sub-fields of each material. Digital learning can be carried out very well if students maximize their skills student's literacy. According to research [46-47] states that digital media is very helpful during the learning process.

\section{CONCLUSION}

In the case of research, DigLIM's STREAM profile in era pandemic COVID-19 has special characteristics between STREAM and Digital Learning Innovation in Madrasah. STREAM DigLIM is one idea to create a learning approach based on science, technology, religion, engineering, art, and mathematics by maximizing the digital potential of the latest technology. The special characteristic of this approach is the integration of religion and art into digital learning. The purpose of this approach is to coach students' basic technology skills and practice students' religious skills during learning. Then the recommendation of researchers to policymakers is making the concept of the STREAM DigLIM approach in learning where there is an emphasis on religious aspects at beginning of learning. This approach is packed with elements of art. The research implications can be used as empirical evidence that digital learning needs to be developed. The limitation of this research only contains the concept of approach and has not applied the approach directly in the classroom, so that future research is needed to analyze student learning outcomes after being given this learning approach.

\section{AUTHOR CONTRIBUTIONS}

All author conceived and designed this study. All author contributed to the process of revising the manuscript, and at the end all authors have approved the final version of this manuscript.

\section{ACKNOWLEDGMENTS}

Thank you to the Ministry of Religious Affairs and the committees of ICMR and AKMI 2021.

\section{REFERENCES}

[1] A.E. Atmojo, Priyo, A. Nugroho, EFL classes must go online! Teaching activities and challenges during COVID-19 pandemic in Indonesia, Register Journal, 13(1) (2020) 49-76.

[2] C.J. Auster, Blended learning as a potentially winning combination of face-to-face and online learning: An exploratory study, Teaching Sociology, 44(1) (2016) 39-48.

[3] S. Huda, A. Rinaldi, S. Suherman, I. Sugiharta, D. W. Astuti, O. Fatimah, A. E. Prasetiyo, Understanding of mathematical concepts in the linear equation with two variables: Impact of elearning and blended learning using google classroom, Al-Jabar: Jurnal Pendidikan Matematika, 10(2) (2019) 261-270.

[4] K. Dewi, T. Pratisia, A.K. Putra, Implementasi pemanfaatan google classroom, google meet, dan instagram dalam proses pembelajaran online menuju abad 21, Jurnal Integrasi dan Harmoni Inovatif Ilmu-Ilmu Sosial, 1(5) (2021) 533-541.

[5] R. Buga, I. Căpeneaţă, C. Chirasnel, A. Popa, Facebook in foreign language teaching-A tool to improve communication competences, ProcediaSocial and Behavioral Sciences, 128 (2014) 93-98.

[6] E. Budiman, U. Hairah, Decision Making Analysis for Free Internet Quota Assistance Online Learning during the Covid-19 Pandemic,In IOP Conference Series: Materials Science and Engineering, 1071(1), pp. 012023, 2021.

[7] N. Davidovitch, M. Belichenko, Facebook Tools and Digital Learning Achievements in Higher Education, Journal of Education and e-learning Research, 5(1) (2018) 8-14.

[8] E. Sofi, Pembelajaran Berbasis E-Learning Pada Mata Pelajaran Sejarah Kebudayaan Islam Kelas VIII Madrasah Tsanawiyah Negeri, Tanzhim, 1(1) (2017) 49-64

[9] A. Purwantoro, S. Asari, N. Maruf, The Effectiveness of E-Learning Madrasah in English Teaching and Learning, Budapest International Research and Critics Institute): Humanities and Social Sciences, 4(3) (2021) 5234-5244.

[10] S. Dhawan, Online learning: A panacea in the time of COVID-19 crisis, Journal of Educational Technology Systems, 49(1) (2020) 5-22.

[11] S. Lestari, A. Santoso, The roles of digital literacy, technology literacy, and human literacy to encourage work readiness of accounting education 
students in the fourth industrial revolution era, $\mathrm{KnE}$ Social Sciences, (2019) 513-527.

[12] Rizaldi, D. Riyan, A. Doyan, Z. Fatimah, M. Zaenudin, M. Zaini, Strategies to Improve Teacher Ability in Using The Madrasah E-Learning Application During the COVID-19 Pandemic, International Journal of Engineering, Science and Information Technology, 1(2) (2021) 1-6.

[13] K. Heggart, J. Yoo, Getting the most from Google Classroom: A pedagogical framework for tertiary educators, Australian Journal of Teacher Education, 43(3) (2018) 140-153.

[14] Rokhimawan, M. Agung, I. Istiningsih, S. Sukiman, The Concept Of Elective-Coordinative Curriculum Model In Level Of Bachelor Degree At Department Of Education Teacher Madrasah Ibtidaiyah In Indonesia, International Journal of Scientific \& Technology Research, 9(1) (2020) 2011-2017.

[15] M.A. Lubis, M. M Yunus, M.A Embi, S. Sulaiman, and $\mathrm{Z}$ Mahamod, Systematic steps in teaching and learning Islamic education in the classroom, Procedia-Social and Behavioral Sciences, 1(7) (2010) 665-70.

[16] F. Sartika, M. Ritonga, A. Rasyid, Implementation of Islamic Religious Education in Madrasah Ibtidaiyah During Covid-19 Pandemic, Khalifa: Journal of Islamic Education, 4(2) (2020) 1442.

[17] H.N. Perdani, R. Azka, Teknologi Dan Pembelajaran Matematika Generasi Milenial, Prosiding Sendika, 5(1) (2019) 1-7.

[18] A.J. Renish, Art Education, Literacy, and English Language Learners: Visual Arts Curriculum to Aid Literacy Development, Online Submission, 2016.

[19] A.S. Ngozi, Influence of gender on attitude towards the use of social media for continuing professional development among academic librarians in Nigeria, Information and Learning Science, 17(15) (2018) $550-564$.

[20] S. Sabine, J. Guggemos, M. Sailer, Technologyrelated knowledge, skills, and attitudes of pre-and in-service teachers: The current situation and emerging trends, Computers in Human Behavior, 115 (2021) 106552.

[21] C.H Chen, C.C Tsai, In-service teachers' conceptions of mobile technology-integrated instruction: Tendency towards student-centered learning, Computers \& Education, 170(1) (2021), 104224.

[22] C.D. Zepeda, J.E. Richey, P. Ronevich, T.J. NokesMalach, Direct instruction of metacognition benefits adolescent science learning, transfer, and motivation: An in vivo study, Journal of Educational Psychology, 107(4) (2015) 954.

[23] P. Pardimin, N. Arcana, and D. Supriadi, Developing media based on the information and communications technology to improve the effectiveness of the direct instruction method in mathematics learning, Journal for the Education of Gifted Young Scientists, 7(4) (2019) 1311-1323.

[24] N.D. Herman, J. Maknun, M.S. Barliana, R. Mardiana, Technology Literacy Level of Vocational High School Students. In 5th UPI International Conference on Technical and Vocational Education and Training, pp. 519-522, Atlantis Press, 2019.

[25] B.A. Sumantri, N. Ahmad, Teori Belajar Humanistik Dan Implikasinya Terhadap Pembelajaran Pendidikan Agama Islam, Fondatia, 3(2) (2019) 1-18.

[26] Pratama, Y. Anjas, Relevansi teori belajar behaviorisme terhadap pendidikan agama islam, Jurnal Pendidikan Agama Islam Al-Thariqah, 4(1) (2019) pp. 38-49.

[27] Kementrian Agama, 2019, https://diy.kemenag.go.id/5578-kemenag-mulaiterapkan-e-learning-madrasah.html

[28] Kementrian Agama, 2019 https://madrasah2.kemenag.go.id/read/20201124/3 07/sinergi-indonesia-uea-500ribu-siswa-madrasahnikmati-platform-pembelajaran-digital-2021

[29] L. Ming-Hung, and H. Chen, A study of the effects of digital learning on learning motivation and learning outcome, Eurasia Journal of Mathematics, Science and Technology Education, 13(7) (2017) 3553-3564.

[30] M.P. Dewi, M.B.N. Wajdi, Distance learning policy during pandemic COVID-19, Journal of Education and Technology, 4(3) (2021), 325-333.

[31] A. Sypsas, E. Toki, J. Pange, Supporting undergraduate students via Webinars, In 2015 International Conference on Interactive Mobile Communication Technologies and Learning, pp. 227-231. IEEE, 2015.

[32] Kristina, Marilin, R.N. Sari, E.S. Nagara, Model Pelaksanaan Pembelajaran Daring pada Masa Pandemi Covid 19 di Provinsi Lampung, Idaarah, 4(2) (2020) 200-209.

[33] F.T. Leow, M. Neo, Interactive multimedia learning: Innovating classroom education in a Malaysian university, Turkish Online Journal of Educational Technology, 13(2) (2014) 99-110. 
[34] Widyaningsih, S. Wahyu, I. Yusuf, Implementation of Project-Based Learning (PjBL) Assisted by ELearning through Lesson Study Activities to Improve the Quality of Learning in Physics Learning Planning Courses, International Journal of Higher Education, 9(1) (2020) 60-68.

[35] D.R. Liasari, H. Prastyo, Developing Media to Teach Writing Skill for EFL Learners at Indonesia, Proceedings International Conference on Indonesian Islam, Education and Science, 2016.

[36] A.S. Situmorang, Microsoft teams for education sebagai media pembelajaran interaktif meningkatkan minat belajar, Sepren, 2(1) (2020), 30-30.

[37] G.R. Morrison, S.J. Ross, H.K. Kalman, Designing effective instruction, John Wiley \& Sons, 2019.

[38] S. Sutiah, S. Supriyono, Software testing on elearning Madrasahs using Blackbox testing, IOP Conference Series: Materials Science and Engineering, 1073(1) (2021) 012065.

[39] F.A. Mokhtar, H. Dzakiria, Illuminating the potential of Edmodo as an interactive virtual learning platform for English language learning and teaching, Malaysian journal of distance education, 2015.

[40] C. Blundell, K. Lee, S. Nykvist, Digital learning in schools: Conceptualizing the challenges and influences on teacher practice, Journal of Information Technology Education: Research, 15 (2016) 535-560.

[41] R.M. Simamora, The Challenges of online learning during the COVID-19 pandemic: An essay analysis of performing arts education students, Studies in Learning and Teaching, 1(2) (2020) 86-103.

[42] M. Mather, A. Sarkans, Student perceptions of online and face-to-face learning, International Journal of Curriculum and Instruction, 10(2) (2018) 61-76.

[43] A. Abidah, H. N. Hidaayatullaah, R. M. Simamora, D. Fehabutar, L. Mutakinati, The impact of covid19 to indonesian education and its relation to the philosophy of "merdeka belajar", Studies in Philosophy of Science and Education, 1(1) (2020) 38-49.

[44] H. Mubarok, N.S. Safitri, A.S. Adam, The Novelty of Religion and Art: Should We Combine with STEM Education?, Studies in Philosophy of Science and Education, 1(3) (2020) 97-103.

[45] Nuangchalerm, Prasart, V. Prachagool, T. Prommaboon, J. Juhji, I. Imroatun, and K. Khaeroni,
Views of Primary Thai Teachers toward STREAM Education, International Journal of Evaluation and Research in Education, 9(4) (2020) 987-992.

[46] Sulisworo, Dwi, F. Suryani, The effect of cooperative learning, motivation and information technology literacy to achievement, International Journal of Learning \& Development, 4(2) (2014) pp. 58-64.

[47] E.P. Ulpa, M.M. Adha, D.S. Putri, A.T. Hartino, Penggunaan Perangkat Teknologi, Informasi dan Komunikasi untuk Membantu Pelaksanaan Kegiatan Pembelajaran di Masa Pandemik Covid-19 (1) (2021) 312-322. 